\title{
BIOSECURITY AND ANTIMICROBIAL USE PRACTICES IN LIVE BIRD MARKETS WITHIN ABEOKUTA METROPOLIS, SOUTHWEST, NIGERIA: A PRELIMINARY SURVEY
}

\author{
Oluwawemimo Adebowale ${ }^{1}$, Motunrayo Makanjuola ${ }^{1}$, Noah Bankole², \\ Adeyemo Olanike ${ }^{3}$, Ayomikun Awoseyi ${ }^{4}$, Olajoju Jokotola Awoyomi ${ }^{1}$ \\ ${ }^{1}$ Department of Veterinary Public Health and Preventive Medicine, \\ Federal University of Agriculture, Abeokuta, Nigeria \\ ${ }^{2}$ Department of Veterinary Microbiology, \\ Federal University of Agriculture, Abeokuta, Nigeria \\ ${ }^{3}$ Department of Veterinary Public Health and Preventive Medicine, \\ University of Ibadan, Nigeria \\ ${ }^{4}$ Department of Mathematics and Computer Sciences, \\ First Technical University, Ibadan, Nigeria
}

Received 5 January 2021; Received in revised form 1 July 2021; Accepted 13 July 2021

\begin{abstract}
The development of an antimicrobial stewardship plan (AMSP) for live bird sellers (LBS) requires an understanding of the current biosecurity status, antimicrobial use (AMU) and the practices involved in live bird selling (e.g., drivers, sellers, etc.) which is a direct source of poultry meat for human consumption. Seven Live Bird Markets (LBMs) within Abeokuta, Ogun State were surveyed using a semi-structured questionnaire. Data on LBMs characteristics, LBS demographics, biosecurity, and AMU practices, awareness on Antimicrobial Resistance (AMR), as well as preferred channels of information on antimicrobial stewardship were gathered. A total of 40 consenting LBS with $82.5 \%$ female and $17.5 \%$ male participants were included in the study. The participants' mean age was 45.3 years ( $\mathrm{SD} \pm 11.9$, range: $23-70$ years). Laying hens, broilers, and cockerels were the main poultry types sold by LBS. Antimicrobials (AMs) were used for growth promotion (57.5\%), therapeutic $(40.0 \%)$, and prophylactic $(2.5 \%)$ purposes. Tetracycline, metronidazole, and chloramphenicol were the most frequently used AMs. The majority of the participants (90.0\%) have treated birds based on their empirical experience, with little or no inputs from veterinarians. Biosecurity and AMU practices were generally low $(54.0 \%$ and $34.0 \%$, respectively). The contact with veterinarians was associated with satisfactory biosecurity practices $(\mathrm{p}=0.049)$. No significant factors were found to be linked with AMU. This study has provided recent evidence-based data on practices in poultry management among LBS in Abeokuta, Ogun state. The findings would be useful for policy decisions and the development of AMSP on prudent AMU among LBS.
\end{abstract}

Key words: antimicrobial use, biosecurity, live bird markets, live bird sellers, risk factors, Abeokuta

\section{INTRODUCTION}

The poultry sector, which is the most commercialized agricultural sub-sector in Nigeria, has been expanding rapidly in the past years with

Corresponding author: Dr. Oluwawemimo Adebowale, $\mathrm{PhD}$ E-mail address: adebowaleoluwawemimo1@gmail.com Present address: Department of Veterinary Public Health and Preventive Medicine, Federal University of Agriculture, Abeokuta, Nigeria Phone: +2349085608043

Copyright: (C) 2021 Adebowale O. This is an open-access article published under the terms of the Creative Commons Attribution License which permits unrestricted use, distribution, and reproduction in any medium, provided the original author and source are credited. Competing Interests: The authors have declared that no competing interests exist.

Available Online First: 20 August 202

Published on: 15 October 2021

https://doi.org/10.2478/macvetrev-2021-0024 the current total population estimated at 200 million (1). There are three main poultry production systems in Nigeria: intensive commercial poultry - large flocks of modern hybrids; semi-intensive poultry - a blend of extensive and intensive systems; and extensive poultry - smallholder households raising small flocks of indigenous birds. Poultry production takes place in all parts of the country of which $25 \%$ are commercial, $15 \%$ are semi-commercial, and $60 \%$ are farmed in backyards (1). The industry has become diversified with a variety of business interests such as egg production, broiler production, hatchery, and poultry equipment business (2). Due to the high poultry meat demand by the growing population of Nigeria, the production has increased from 56,700 tons 
in 1970 to 239,947 tons in 2019 , with an average annual growth rate of $3.26 \%$.

The high potential of the country's poultry industry has been hampered by several factors such as the poor biosecurity level, bacterial, and viral poultry diseases (3). Poor hygiene and sanitary measures, and inadequate disease preventive strategies have been indicated to significantly contribute to the unsustainability of poultry production, the indiscriminate use of antimicrobials (AMs), and the occurrence of AM resistance in the poultry industry (1). The AMs' availability without appropriate veterinary prescription and unregulated access to veterinary drugs over the counter encourage the misuse of these drugs by livestock farmers $(4,5)$.

The demand for animal proteins for human consumption is rising globally. Many nations, especially the low and middle-income countries (LMICs), are saddled with the responsibilities to meet sustainable development goals (SDG) 2 and 3 , which intend to increase the animal protein per capita consumption by the year 2030 (5). The animal protein demand from the growing human populations in the LMICs has facilitated the expansion of intensive animal farming practices and systems in which AMs are used routinely to maintain health and to increase productivity (6). Thus, the higher incomes have increased the AM consumption in the LMICs $(7,8)$. AMs are used for therapeutic and metaphylactic purposes when the positive diagnosis in one animal prompts entire flock or herd treatment (9). AMs are also widely used as prophylactics in sub-therapeutic doses which are administered to counteract the adverse effect of stress responses and growth promoters (10).

Livestock farmers' reliance on AMs for nontherapeutic purposes has been projected to increase by $165 \%$ by 2030 (7). Nigeria stands amongst five countries with the greatest projected percentage in AM consumption by 2030 (163\%) with the possible imminent increase in AM residues and antimicrobial resistance (AMR) (7). The other countries are Myanmar (205\%), Indonesia (202\%), Peru (160\%), and Vietnam (157\%). AM consumption in poultry in low resource settings has exceeded levels observed in high-income countries (8). The live bird markets in Nigeria are essential to the poultry farmers for the marketing of birds to the consumers. They are the preferred places for poultry meat purchase. The LBMs are located primarily in specific areas of general markets of urban areas and have a permanent structure (stall) in which birds are housed until sold (11). Poultry farmers and middlemen tend to transport and sell large numbers of live birds of various species (broilers, layers, and cockerels) to multiple vendors/live bird sellers in different open markets (12). The birds from different farms are mixed during this process (13). They are slaughtered and processed (dressed) at the markets before being sold to the consumers. Therefore, the LBMs and its trade network (farms, roads, abattoirs, slaughter slabs, and households) have been associated with the dissemination of poultry diseases of high public health and economic importance (avian influenza, Newcastle disease), AM residues, and persistent pool of AM multidrug-resistant (MDR) pathogens in the food chain and environment $(4,13)$.

Poultry is a potential source of MDR pathogens, which could be spread to human populations in Nigeria. There are evidences that poultry harboring drug-resistant $E$. coli enhanced the transmission to poultry workers on farms and live bird sellers (LBS) in Abuja, Nigeria (4). AMR is emerging as a global health threat as MDR are increasing mortality and economic burden in humans and livestock animals, and Nigeria is no exception to this challenge (3). If appropriate measures are not taken to reduce MDR pathogens, it is estimated that by 2050 around 10 milion people may die and about US $\$ 100$ trillion per year could be lost (14). The "One Health" concept, which considers collaborative efforts of the government, medical, veterinary, and environmental health disciplines is critical in taking this challenge (15). The "one health" approach is a developing concept in Nigeria. For many years there has been gross negligence in cross-discipline interactions and collaborations between the Nigerian veterinary medical and human medical professions. Therefore, there is the need to build solid "One Medicine" framework through continuous awareness creation about the "one health concept" in various health disciplines, among the public and government, and non-governmental institutions (16). The high public health risk growing LBMs tendency, high demand for poultry meat and patronages from the neighboring communities necessitate higher involvement of government and veterinary professionals in promoting responsible use of these antimicrobials in poultry and other food animal farming systems (7).

The knowledge of the current state of AMU is necessary for developing operable educational programs and guidelines on antimicrobial stewardship (AMS) among LBS. The current study aimed to gather preliminary data on the biosecurity status and AMU pattern in LBMs in Abeokuta, Ogun State, Nigeria. 


\section{MATERIAL AND METHODS}

\section{Study area}

The study was conducted in Abeokuta, Ogun State, which is in the South-West region of Nigeria and the state capital. Seven LBMs within Abeokuta were included: Gbonagun, Kuto, Lafenwa, Itoku, Ago-ika, Asero, and Asejere (Fig. 1). All the LBMs were within the Ogun central district which is one of the three senatorial districts in Ogun state. Ogun State with its capital in Abeokuta is the largest producer of chicken in Nigeria and was selected for this study (17).

In Nigeria, LBMs are found within most markets in urban areas. LBM capacity varies between a few hundred to several thousand birds and the number of traders from a dozen to a hundred (18). These numbers have however increased due to the growing demand for animal products as well as the need to generate incomes in urban settings (19). Despite the existence of bird seller associations, there are no strict regulations on the overall functioning of the markets resulting in no control on birds' location or records of their origin (18).

In the seven Abeokuta LBMs, LBS operated from 7:00 am to 7:30 pm from Monday to Saturday. However, some LBS were selling on Sundays at Kuto and Lafenwa LBMs. The number of sellers ranged from five to fifteen.
Study design, sample size estimation, and recruitment of live bird market

A cross-sectional study was conducted among seven LBMs within the Abeokuta city from August to November 2020. Our target population was the entire LBMs and LBS in the Abeokuta metropolis. All LBMs from the list of registered markets (six) within Abeokuta metropolis were recruited as provided by the Department of Livestock, Ministry of Agriculture, Ogun State, Nigeria. One additional LBM included in this study was not unregistered.

Based on the population size of LBS in Abeokuta $(\mathrm{N}=100)$ and considering a simple random sampling, the sample size for this study was calculated by using Epi Info 7 with the following equation: $n=\left[Z^{2} P(1-P)\right] / d^{2}$ where ' $n$ ' is the required sample size, ' $Z$ ' is the multiplier from a standard normal distribution (1.96) at a probability level of 0.05 , ' $\mathrm{P}$ ' is the estimated prevalence for which we used the default value $(50 \%)$, considering that this was the approximate percentage of respondents with a poor level of biosecurity and AMU, and ' $\mathrm{d}$ ' is the desired precision for the estimate $( \pm 5 \%)$. A total of 79 LBS was estimated for the survey. Twelve LBS from each LBM were expected to participate. However, LBS were selected using nonprobabilistic convenience sampling based on their willingness to participate in the study.

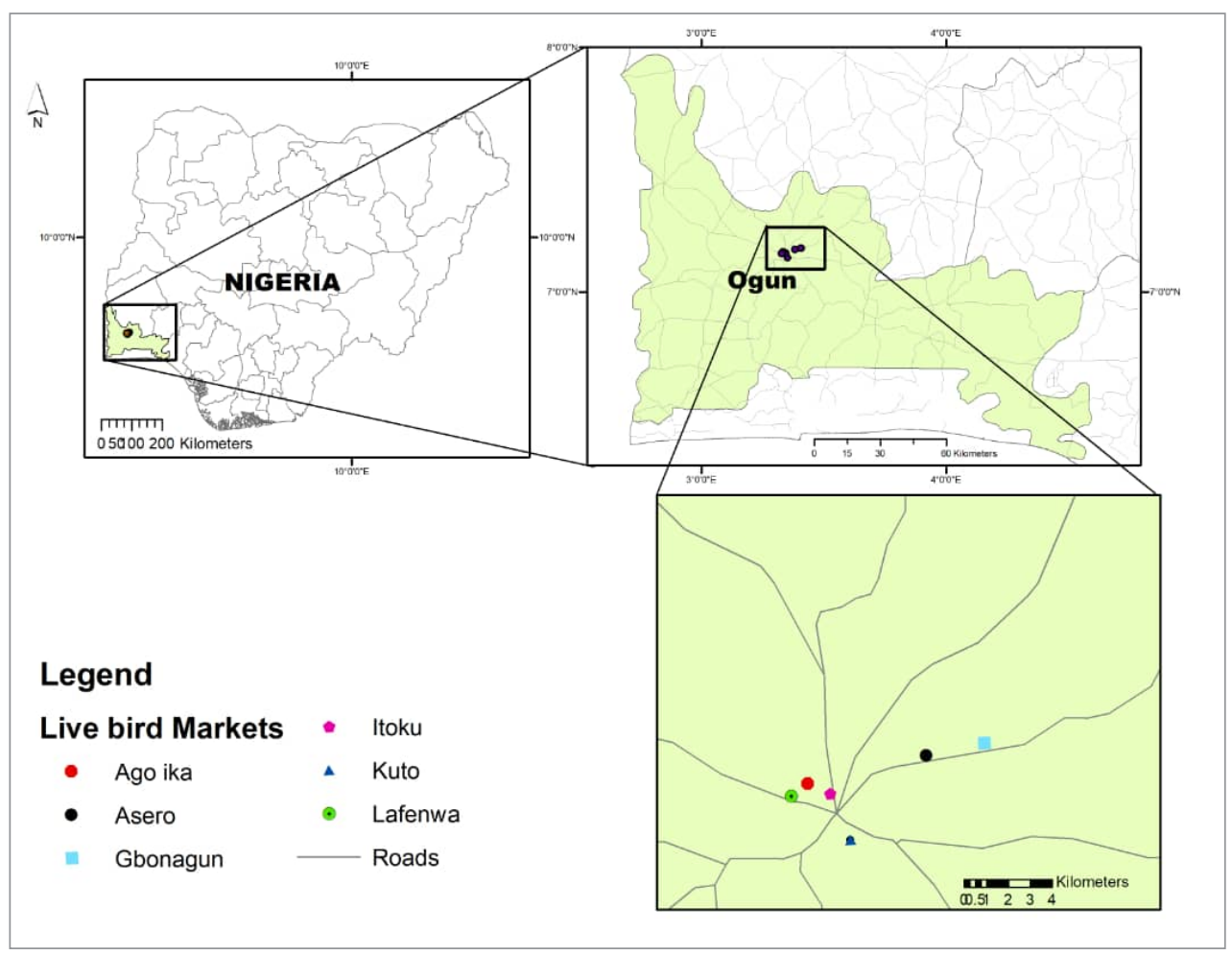

Figure 1. Spatial distribution of LBMs investigated in this study 
Before the commencement of the study, a permission and signed consent were obtained from the Chairman of the Ogun State branch of the Poultry Farmers' Association of Nigeria (PFAN) and the coordinators of each LBM. Verbal consent was obtained from the participating LBS. The term LBS was used for a person that was selling poultry on the market stalls bred by another owner. Each of the LBMs was assigned to a single investigator. To ensure biosecurity, the investigators visited the LBMs every other week and had the questionnaire filled by interviewing the LBS on the same stalls from August to November 2020. The investigators were provided with clean protective coverings and disinfected boots on every visit. All participants were given detailed information about the aims and outcomes, which include feedback seminar and antimicrobial stewardship training workshop for LBS. Participation in the study was voluntary i.e., those willing to participate were interviewed. Personal identifiers were not collected and information from respondents was treated confidentially. Every participant was notified of his/her right to discontinue participation at any stage of the study according to the World Medical Association Declaration of Helsinki, 2001 (20). A total of 40 LBS voluntarily participated in the survey.

The College of Veterinary Medicine Research Ethics (CREC), Federal University of Agriculture Abeokuta, Ogun State, Nigeria, reviewed and approved the study design and the informed consent procedures (Ref. no FUNAAB/COLVET/ CREC/2020/02/01).

\section{Questionnaire design and data collection}

The questionnaire used for the survey was a modified version from previous studies $(3,9)$ approved by the College of Veterinary Medicine Research Ethics (CREC), Federal University of Agriculture Abeokuta, Ogun State, Nigeria. The questionnaire was written in English and consisted of four sections with a total of 48 items. The sections were as follows: 1) General data on the LBMs characteristics (16 questions); 2) Poultry sellers' demographics and biosecurity practices (14 questions); 3) AMU, practices, and awareness on AMR (17 questions); 4) Preferred information channel on AMS training (1). The questionnaire was pretested on five LBS. Data from the pretesting was not included in the final analysis. In addition to the questionnaire, investigators were instructed to observe for the presence of wild migratory birds in the LBMs. The questionnaire was filled by direct interview of the LBS, whereas the verbal communication was conducted in Yoruba which is an indigenous dialect, fluently spoken by all investigators.

\section{Statistical analysis}

Statistical analysis was performed for all variables and presented in frequencies and proportions/percentages using Microsoft Excel ${ }^{\circledR}$ (2013) and SPSS version 23.0. Due to the small sample size $(<50)$, the normality of numerical variables was performed by the Shapiro-Wilk test $(p>0.05)$. The distribution of the data was assessed by descriptive analysis. Values were presented as mean $\pm \mathrm{SD}$ for normally distributed or as median with minimum and maximum range for not normally distributed values. The scoring of LBS biosecurity (sum score=13) and AMU practices (sum score $=16$ ) was based on responses provided by participants. The accurate responses were scored with " 1 ", whereas inaccurate with "0". The scores were converted to percentile values by dividing the obtained with the possible maximum scores, multiplied by 100 . The overall scores of participants were re-categorized based on Bloom's cut-off point (21). The overall biosecurity and AMU practice scores among study participants were re-grouped into three levels, 80.0-100\% (Good), 60.0-79.9\% (Satisfactory), and $<60.0 \%$ (Poor). Since no respondent fell within the good category, the other levels were used in the further analysis. Meanwhile, the normal Q-Q plot was performed to test the normality of the distribution of biosecurity and AMU scores. The Spearman's rho was later performed to test the correlation between scores. Factors (LBS demographics) associated with biosecurity and AMU practices were determined using Pearson's Chi-Square or Fischer's exact test (where cells have expected count less than 5 ), and were considered significant at $\mathrm{p} \leq 0.05$. Finally, the analyzed data were organized and presented in tabular, graphical, and narrative formats as necessary.

\section{RESULTS}

\section{Demographics of live bird sellers}

A total of 40 LBS, $82.5 \%$ females and $17.5 \%$ males, from across various LBMs in Abeokuta, Ogun State, participated in the study. The participants' mean age was $45.3 \pm 11.9$ years 
Biosecurity and antimicrobial use practices in Nigeria's live bird markets

Table 1. Characteristics of participants (LBS) from the seven LBMs investigated in Abeokuta, Ogun State $(\mathrm{n}=40)$

\begin{tabular}{|c|c|c|c|}
\hline Variables & Frequency & Percent & $95 \% \mathrm{CI}$ \\
\hline \multicolumn{4}{|l|}{ Sex } \\
\hline Male & 7 & 17.5 & $8.4-32.3$ \\
\hline Female & 33 & 82.5 & $67.7-91.6$ \\
\hline \multicolumn{4}{|c|}{ Marital Status } \\
\hline Single & 3 & 7.5 & $1.9-20.6$ \\
\hline Married & 37 & 92.5 & $79.4-98.1$ \\
\hline \multicolumn{4}{|c|}{ Age (in years) } \\
\hline $20-30$ & 5 & 12.5 & $4.9-26.6$ \\
\hline $31-40$ & 10 & 25.0 & $14.0-40.4$ \\
\hline $41-50$ & 15 & 37.5 & $24.1-53.0$ \\
\hline $51-60$ & 6 & 15.0 & $6.8-29.5$ \\
\hline $61-70$ & 4 & 10.0 & $3.4-23.6$ \\
\hline \multicolumn{4}{|c|}{ Educational level } \\
\hline Informal & 5 & 12.5 & $4.9-26.6$ \\
\hline Primary & 16 & 40.0 & $26.3-55.4$ \\
\hline Secondary & 16 & 40.0 & $26.3-55.4$ \\
\hline Tertiary & 1 & 2.5 & $<0.01-14.0$ \\
\hline N/A & 2 & 5.0 & $0.5-17.4$ \\
\hline \multicolumn{4}{|c|}{ Primary Occupation (live bird) } \\
\hline No & 4 & 10.0 & $3.4-23.6$ \\
\hline Yes & 36 & 90.0 & $76.4-96.6$ \\
\hline \multicolumn{4}{|c|}{ Membership of the LBS Association } \\
\hline No & 6 & 15.0 & $6.8-29.5$ \\
\hline Yes & 34 & 85.0 & $70.5-93.3$ \\
\hline \multicolumn{4}{|c|}{ Years in the live bird business } \\
\hline $0-10$ & 7 & 17.5 & $8.4-32.3$ \\
\hline $11-20$ & 6 & 15.0 & $6.8-29.5$ \\
\hline $21-30$ & 5 & 12.5 & $4.9-26.6$ \\
\hline $31-40$ & 3 & 7.5 & $1.9-20.6$ \\
\hline N/A & 19 & 47.5 & $32.9-62.5$ \\
\hline
\end{tabular}

$\mathrm{N} / \mathrm{A}=$ Not available

(range: $23-70$ years). The majority were married (37/40, 92.5\%), registered with the LBS association $(34 / 40,85.0 \%)$, and had informal or primary school level education $(21 / 40,52.5 \%)$. Moreover, others obtained secondary $(16 / 20,21.0 \%)$ and tertiary education $(1 / 40,2.5 \%)$. Live bird slaughtering and selling were described as the main livelihood by participants $90.0 \%$ (36/40), and the mean number of experience in the business was $20.0 \pm 10.9$ years. More than half of the LBS had no previous contact with veterinary services (Table 1).

\section{Live bird market characteristics and biosecurity}

A typical LBM in Abeokuta is shown in Fig. 2. Poultry types present in the LBMs surveyed included laying hens, broilers and cockerels (Fig. 3). Most LBS (75.0\%) reported that the poultry was situated in metal cages. Wooden or raffiabased enclosing cases were used as other types of cages.

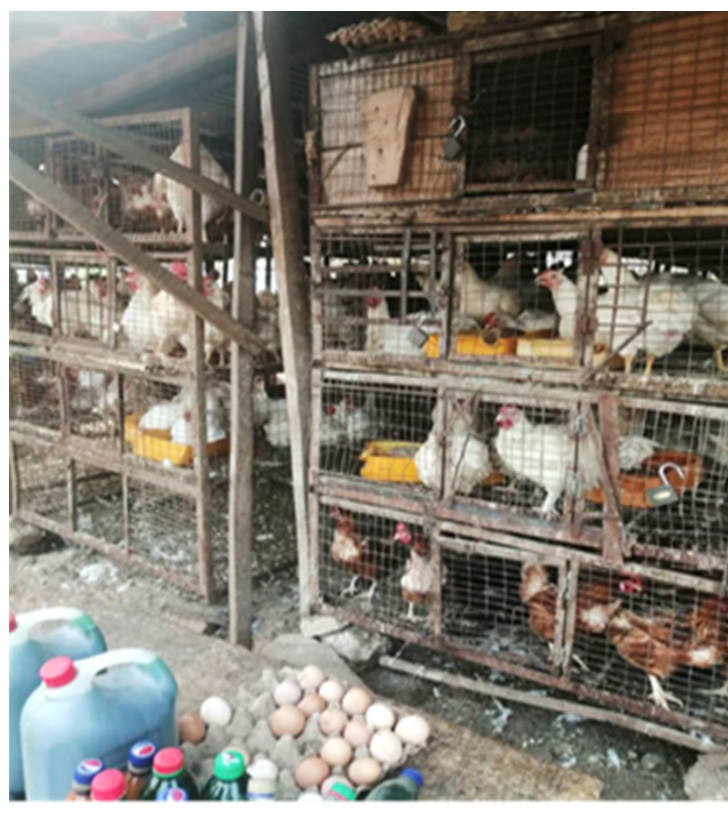

Figure 2. A typical LBM in the study area, Abeokuta, Ogun State. This image depicts the unclean metal cages and surroundings with various poultry of different ages 


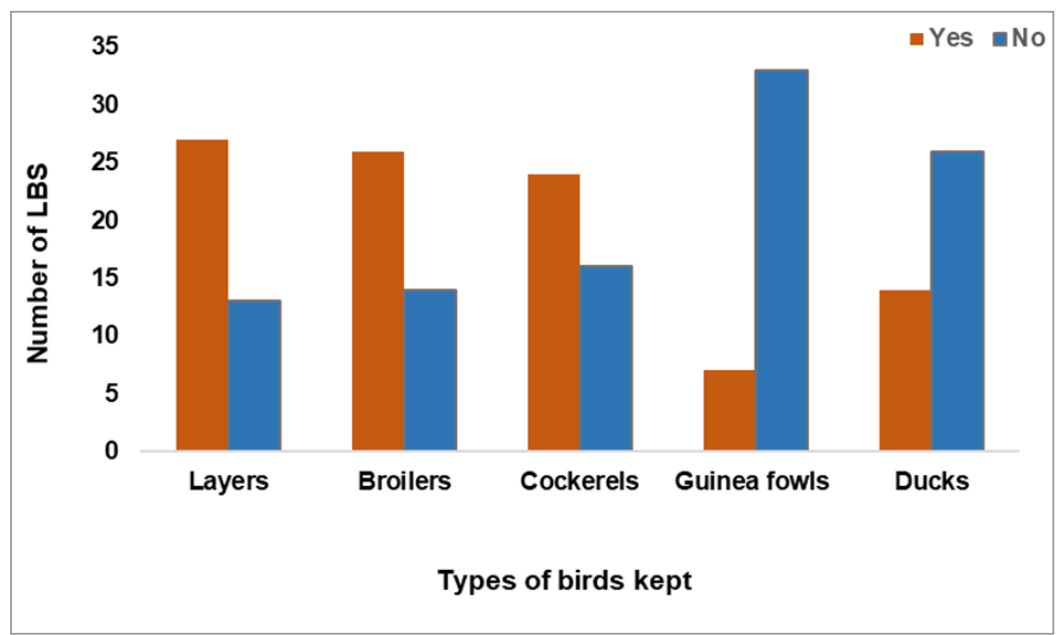

Figure 3. The number of LBS and the various poultry types kept in Abeokuta, Ogun State

The total number of poultry was as follows: laying hens (890, median 30.0), broilers (625, mean 24.1 \pm 8.1 ), and cockerels (485, median 20.0). The total numbers of the other poultry were: guinea fowl $(n=10)$ and ducks $(n=10)$. All the LBMs were established mainly for selling and slaughtering of poultry. The animals were mainly fed by commercial feeds and were provided with well (ground) water.

Concerning biosecurity practices within the LBMs, respondents declared that poultry of various ages was sourced from different farms, mixed, and housed together (Table 2).

No quarantine measures were observed before introducing new poultry into the cages. Furthermore,

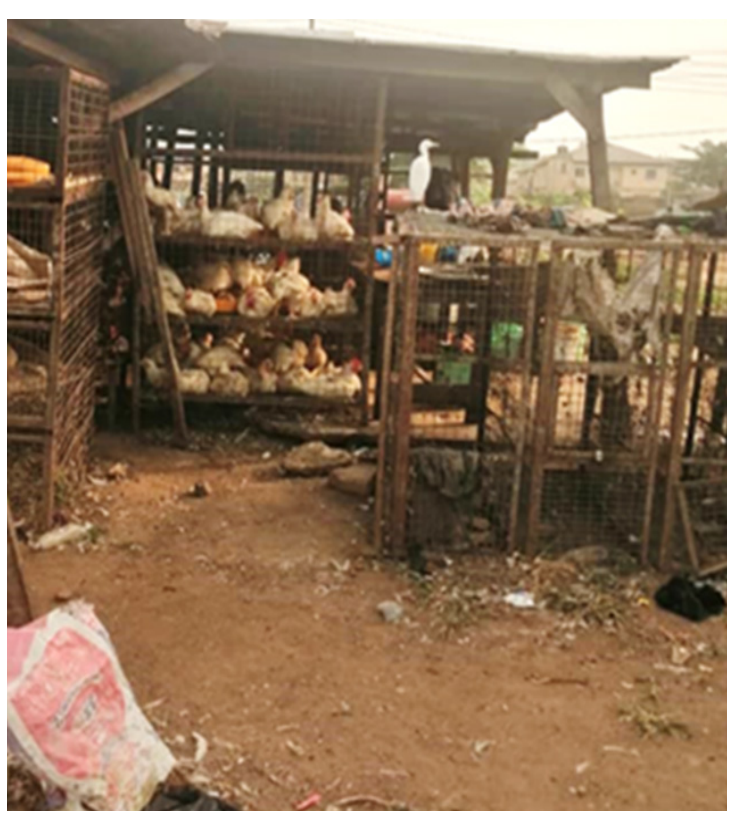

Figure 4. A migratory wild bird perching on a cage close to the caged live birds wild birds were noticed around four LBMs situated within cattle slaughterhouses (Fig. 4). Goats, sheep, and cattle were noticed to be in proximity to the poultry. Daily cleaning of the environment, meat dressing tables, and cages were practiced by $90.0 \%$, $85.0 \%$, and $60.0 \%$ of the participants, respectively. One portion of the participants $(35.0 \%)$ reported disposing of poultry wastes by using municipal waste management services. Another portion of the participants reported disposing of the wastes in open dumps/dustbins $(52.5 \%)$ or rivers $(10.0 \%)$ (Table 2).

The median score for biosecurity practices among surveyed LBS was 54.0\% (minimum 8.0\%, maximum 69.0\%). Approximately, 72.5\% LBS fell within the poor biosecurity category (<60.0\%, range $8.0-54.0 \%)$, while others $(27.5 \%)$ had satisfactory level ranging from 62-69\%. A potentially statistically significant association between biosecurity practices and contact with veterinarians was observed $(\mathrm{p}=0.049)$ (Table 3). On the contrary, the level of biosecurity practices was not associated with LBS demographic profiles such as sex, age, marital status, educational background, and membership in a poultry sellers' association.

\section{Antimicrobial use and antimicrobial resistance}

In this survey, $97.5 \%$ (39/40) of the participants were aware of AMU while 95.0\% declared AM use for poultry treatment. Similarly, 95.0\% were unaware of AMR and its implications such as prolonged treatments of diseases and increased morbidity and mortality in poultry and humans. AMs were most frequently used by LBS for growth promotion in the poultry $(57.5 \%)$. AMs 
Biosecurity and antimicrobial use practices in Nigeria's live bird markets

Table 2. Biosecurity and antimicrobial use among live bird sellers in Abeokuta, Ogun State, Nigeria

\begin{tabular}{|c|c|c|c|c|c|}
\hline Questions/Variables & Options & Score & Responses (n) & $(\%)$ & $95 \%$ CI \\
\hline \multicolumn{6}{|c|}{ Biosecurity } \\
\hline \multirow{2}{*}{ B1. Presence of wild birds } & Yes & 0 & 31 & 77.5 & $62.29-87.90$ \\
\hline & No & 1 & 9 & 22.5 & $12.10-37.70$ \\
\hline \multirow{2}{*}{ B2. Mix bird species and ages } & Yes & 0 & 12 & 30.0 & $17.90-45.50$ \\
\hline & No & 1 & 28 & 70.0 & $54.50-82.00$ \\
\hline \multirow{2}{*}{$\begin{array}{l}\text { B3. Inspection of birds and } \\
\text { processing facilities }\end{array}$} & Yes & 1 & 10 & 25.0 & $14.00-40.30$ \\
\hline & No & 0 & 30 & 75.0 & $59.60-85.90$ \\
\hline \multirow{2}{*}{ B4. Presence of other animals } & Yes & 0 & 16 & 40.0 & $26.30-55.40$ \\
\hline & No & 1 & 24 & 60.0 & $44.60-73.70$ \\
\hline \multicolumn{6}{|c|}{ Same Farm } \\
\hline & Yes & 1 & 1 & 2.5 & $<0.01-14.00$ \\
\hline & No & 0 & 39 & 97.5 & $85.90->99.90$ \\
\hline
\end{tabular}

B5. Source of poultry

Various farms

\begin{tabular}{lccccc} 
& Yes & 0 & 0 & 0.0 & $0.00-10.40$ \\
& No & 1 & 0 & 0.0 & $0.00-10.40$ \\
\hline \multirow{2}{*}{ B6. Clean the environment regularly } & Yes & 1 & 36 & 90.0 & $76.40-96.60$ \\
& No & 0 & 4 & 10.0 & $3.40-23.60$ \\
\hline \multirow{2}{*}{ B7. Clean the cages regularly } & Yes & 1 & 24 & 60.0 & $44.60-73.70$ \\
\hline \multirow{2}{*}{ B8. Clean processing table regularly } & No & 0 & 16 & 40.0 & $26.30-55.40$ \\
& Yes & 1 & 34 & 85.0 & $76.40-96.60$ \\
\hline & No & 0 & 6 & 15.0 & $3.40-23.60$ \\
\hline & Open dumps & & & & $37.50-67.10$ \\
& Yes & 0 & 21 & 52.5 & $32.90-62.50$ \\
& No & 1 & 19 & 47.5 & $3.40-23.60$
\end{tabular}

B9. Disposal waste methods

Municipal waste services

$\begin{array}{lllll}\text { Yes } & 1 & 14 & 35.0 & 26.30-55.40 \\ \text { No } & 0 & 26 & 65.0 & 44.60-73.70\end{array}$

Recycle as fertilizers

$\begin{array}{ccccc}\text { Yes } & 1 & 7 & 17.5 & 8.43-32.30 \\ \text { No } & 0 & 33 & 82.5 & 67.70-91.50\end{array}$

Antimicrobial use

\begin{tabular}{llcccc}
\hline A1. Aware of antimicrobials & Yes & 1 & 39 & 97.5 & $85.90->99.90$ \\
& No & 0 & 1 & 2.5 & $<0.01-14.00$ \\
\hline \multirow{2}{*}{ A2. Use Antimicrobials for poultry? } & Yes & 0 & 38 & 95.0 & $82.60-99.00$ \\
& No & 1 & 2 & 5.0 & $0.50-17.40$ \\
\hline
\end{tabular}




\begin{tabular}{cccccr}
\hline Questions/Variables & Options & Score & Responses (n) & $\mathbf{( \% )}$ & $\mathbf{9 5 \%}$ CI \\
\hline Treat diseases & & & & & \\
& Yes & 1 & 31 & 77.5 & $62.29-87.90$ \\
No & 0 & 9 & 22.5 & $12.10-37.70$
\end{tabular}

A3. For what purpose?

Prevent diseases

$\begin{array}{lllll}\text { Yes } & 0 & 17 & 42.5 & 28.50-57.80 \\ \text { No } & 1 & 23 & 57.5 & 42.20-71.50\end{array}$

Call a veterinarian

$\begin{array}{ccccc}\text { Yes } & 1 & 3 & 7.5 & 1.80-20.70 \\ \text { No } & 0 & 37 & 92.5 & 79.40-98.10\end{array}$

A4. How do you administer drugs?

$\begin{array}{lcccc}\text { Self } & & & & \\ \text { Yes } & 0 & 36 & 90.0 & 76.40-96.60 \\ \text { No } & 1 & 4 & 10.0 & 3.40-23.60\end{array}$

Vet Shops

$\begin{array}{lllll}\text { Yes } & 1 & 16 & 40.0 & 26.30-55.40 \\ \text { No } & 0 & 24 & 60.0 & 44.60-73.70\end{array}$

A5. Where do you obtain antimicrobials for your birds?
Pharmacy shops

$\begin{array}{lllll}\text { Yes } & 0 & 0 & 0.0 & 0.00-10.40 \\ \text { No } & 1 & 0 & 0.0 & 0.00-10.40\end{array}$

Poultry farmers

\begin{tabular}{llllll} 
& Yes & 0 & 0 & 0.0 & $0.00-10.40$ \\
& No & 1 & 0 & 0.0 & $0.00-10.40$ \\
\hline $\begin{array}{l}\text { A6. Are you influenced by } \\
\text { company's brand before use? }\end{array}$ & Yes & 0 & 2 & 5.0 & $0.50-17.40$ \\
& No & 1 & 38 & 95.0 & $82.60-99.00$ \\
\hline
\end{tabular}

Vet prescription

$\begin{array}{ccccc}\text { Yes } & 1 & 7 & 17.5 & 8.43-32.30 \\ \text { No } & 0 & 33 & 82.5 & 67.7-91.50\end{array}$

A7. What influences your use of antimicrobials?

Other live bird sellers

$\begin{array}{lllll}\text { Yes } & 0 & 0 & 0.0 & 0.00-10.40 \\ \text { No } & 1 & 0 & 0.0 & 0.00-10.40\end{array}$

\begin{tabular}{lccccc} 
& My experience & & & & \\
& Yes & 0 & 0 & 0.0 & $0.00-10.40$ \\
& No & 1 & 0 & 0.0 & $0.00-10.40$ \\
\hline A8. Observe withdrawal period & Yes & 1 & 0 & 0.0 & $0.00-10.40$ \\
& No & 0 & 0 & 0.0 & $0.00-10.40$ \\
\hline $\begin{array}{l}\text { A9. Used antibiotics in the last 2 } \\
\text { days }\end{array}$ & Yes & 0 & 14 & 35.0 & $26.30-55.40$ \\
\hline $\begin{array}{l}\text { A10. Slaughtered out of treated bird } \\
\text { in the last 2 days }\end{array}$ & No & 1 & 26 & 65.0 & $44.60-73.70$ \\
\hline
\end{tabular}




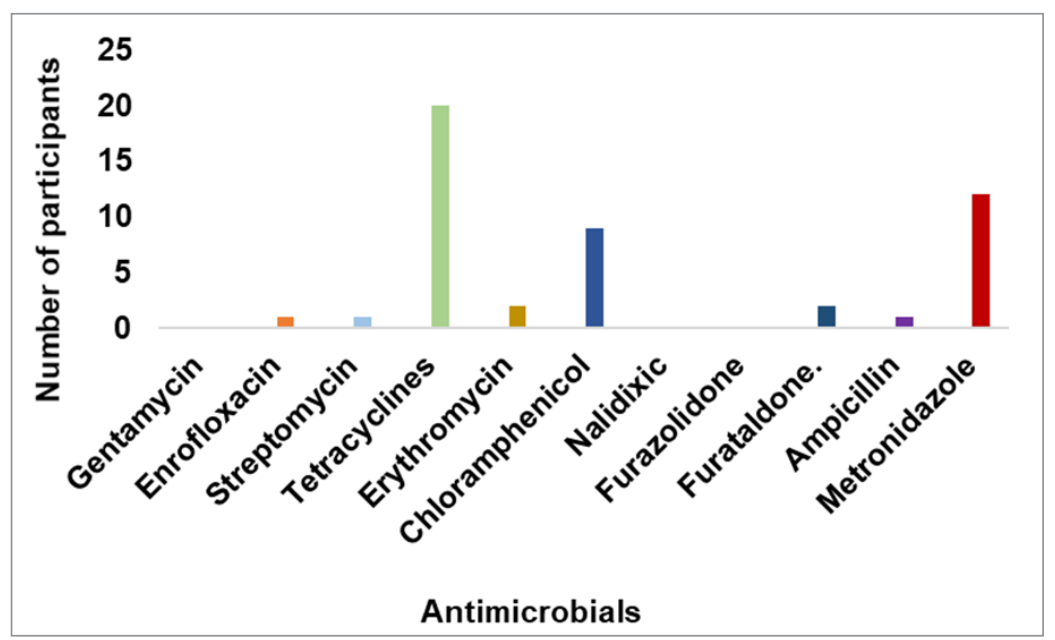

Figure 5. Self-reported distribution of the various antimicrobials used by live bird sellers in Abeokuta, Ogun State

were also used by LBS for therapeutic (40.0\%) and prophylactic $(2.5 \%)$ purposes. LBS $(77.5 \%)$ informed they used AMs only when birds were sick. The majority of participants $(90.0 \%)$ selfadministered AMs to poultry and purchased drugs from veterinary shops $(16 / 40,40.0 \%)$ or human medicine stores $(25.0 \%)$ without veterinary prescriptions. AMs were chosen according to previous experience, accessibility, and cost, whereas company brands, poultry farmers, and veterinarians had little or no effect. Tetracycline, metronidazole, chloramphenicol, erythromycin, and furaltadone were the most common AMs used in LBMs in Abeokuta (Fig. 5). About 35.0\% of the LBS reported that they used tetracycline $(27.5 \%)$, furaltadone $(2.5 \%)$, and metronidazole $(2.5 \%)$ within 48 hours before slaughtering (Table 2).
The mean practice score towards AMU among LBS was poor $(34.0 \%, \mathrm{SD} \pm 12.0 \%)$. Generally, $97.5 \%$ of the participants fell within the poor category $(<60 \%, 13-50 \%)$, while one LBS displayed a satisfactory level with a score of $63.0 \%$. There was a weak negative correlation between biosecurity and AMU, which was not statistically significant $(r=-0.099 ; p=0.54)$. Similarly, none of the demographic variables (sex, marital status, age, educational background, and LBS association membership) were associated with AMU practices (Table 3).

Information channel preferred by LBS for antimicrobial stewardship training

The respondents preferred to receive AMs training information from three main media: radio, seminars, and veterinary officers (Fig. 6).

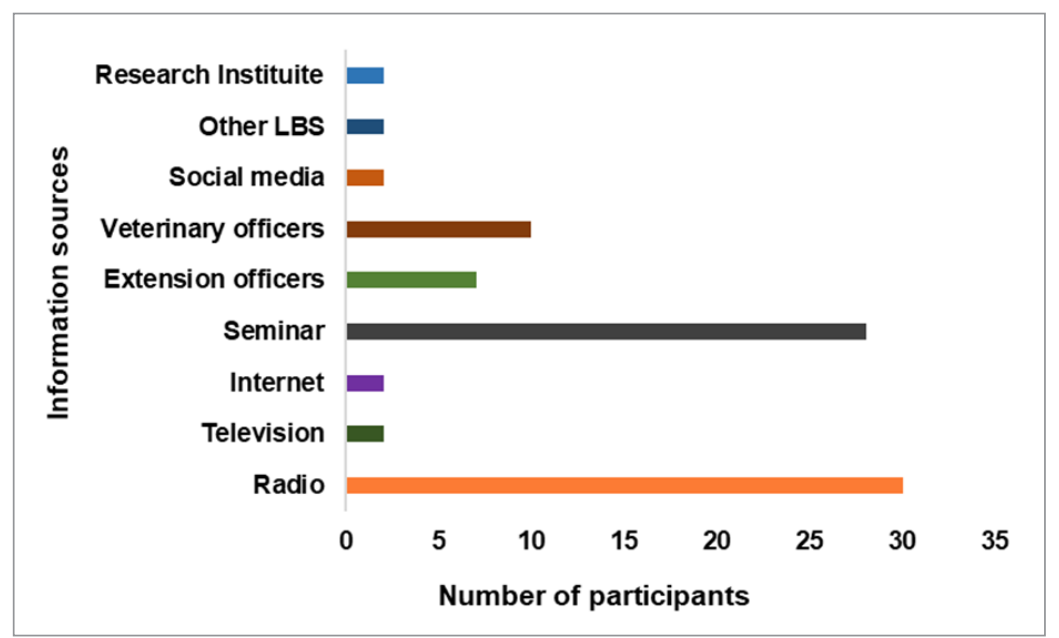

Figure 6. Live bird sellers' self- reported preferred information sources for antimicrobial stewardship training in LBMs surveyed in Abeokuta, Ogun State 
Table 3. Factors associated with the biosecurity and antimicrobial use among live bird sellers in Abeokuta, Ogun State

\begin{tabular}{|c|c|c|c|c|c|c|}
\hline \multirow{2}{*}{ Variables } & \multicolumn{3}{|c|}{ Level of biosecurity practices } & \multicolumn{3}{|c|}{ Level of antimicrobial practices } \\
\hline & Poor & Satisfactory & p value & Poor & Satisfactory & p value \\
\hline \multicolumn{7}{|l|}{ Sex } \\
\hline Male & 6 & 1 & $0.65^{\mathrm{b}}$ & 7 & 0 & $1.00^{\mathrm{b}}$ \\
\hline Female & 23 & 10 & & 32 & 1 & \\
\hline \multicolumn{7}{|c|}{ Marital Status } \\
\hline Single & 2 & 1 & $1.00^{\mathrm{b}}$ & 3 & 0 & $1.00^{\mathrm{b}}$ \\
\hline Married & 27 & 10 & & 36 & 1 & \\
\hline \multicolumn{7}{|c|}{ Age (in years) } \\
\hline $20-30$ & 4 & 1 & $0.71^{\mathrm{b}}$ & 5 & 0 & $0.79^{\mathrm{b}}$ \\
\hline $31-40$ & 7 & 3 & & 10 & 0 & \\
\hline $41-50$ & 12 & 3 & & 14 & 1 & \\
\hline $51-60$ & 3 & 3 & & 6 & 0 & \\
\hline $61-70$ & 3 & 1 & & 4 & 0 & \\
\hline \multicolumn{7}{|c|}{ Educational level } \\
\hline Informal & 5 & 0 & $0.72^{\mathrm{b}}$ & 5 & 0 & $0.45^{\mathrm{b}}$ \\
\hline Primary & 11 & 5 & & 16 & 0 & \\
\hline Secondary & 12 & 4 & & 15 & 1 & \\
\hline Tertiary & 0 & 1 & & 1 & 0 & \\
\hline N/A & 1 & 1 & & 2 & 0 & \\
\hline \multicolumn{7}{|c|}{ Primary occupation } \\
\hline No & 3 & 1 & $1.00^{\mathrm{b}}$ & 4 & 0 & $1.00^{\mathrm{b}}$ \\
\hline Yes & 26 & 10 & & 35 & 1 & \\
\hline \multicolumn{7}{|c|}{ Membership of the poultry sellers association } \\
\hline No & 5 & 1 & $1.00^{\mathrm{b}}$ & 6 & 0 & $1.00^{\mathrm{b}}$ \\
\hline Yes & 22 & 10 & & 33 & 1 & \\
\hline \multicolumn{7}{|c|}{ Contact with veterinarian } \\
\hline No & 18 & 8 & $0.049^{* a}$ & 12 & 0 & $0.47^{b}$ \\
\hline Yes & 11 & 3 & & 17 & 1 & \\
\hline
\end{tabular}

*Significant at $\mathrm{p} \leq 0.05$; $\mathrm{a}=$ Pearson's Chi Square; $\mathrm{b}=$ Fischer's exact test

\section{DISCUSSION}

Over the past few decades, no new major types of antibiotics have been produced and almost all known antibiotics are increasingly losing their activity against pathogenic microorganisms (22). The indiscriminate use of AMs in food animals has a significant public health impact, including the emergence of MDR bacteria that can be transferred to consumers and consequently could increase the morbidity and mortality rates. In 2016, the General Assembly of the United Nations recognized inappropriate AMU in animals as a leading cause of AMR (23).

The current use of AMs in LBMs is critical because many families in Nigeria depend on poultry products for consumption especially the meat, which is either purchased as live bird or dressed. Unfortunately, AMs are administered at this critical point of sale jeopardizing public health and promoting the development of AMR. Also, the LBMs are the direct link between the live, freshly slaughtered poultry and the consumers and are the potential spot for transmission of foodborne zoonoses (24). Poultry products are highly demanded worldwide. Antimicrobials are frequently used in poultry farming. This practice results in AM residues which may increase microbial resistance among poultry and consumer populations (22). It is crucial to have data on AMU in food animals in order to establish appropriate policies, control on AM use, and effective AMS training. Strategies to improve AMS and responsible use should exploit the patronclient relationship which provides the social and information network for small-scale farmers (25).

In this study, a gender preference for live bird business in Abeokuta was observed with the 
majority of participants being females $(82.5 \%)$ unlike poultry farms in various other of Nigeria, which are dominated by male workers $(4,17,29)$. This is not surprising because culturally, women are saddled with the responsibilities of domestic chores and other related activities, unlike men who are expected to carry out tougher jobs such as the herding of animals. Furthermore, family poultry fulfils multiple roles within household livelihood strategies, and sales of the poultry products are more likely to be managed by women and children (26). Women may make the decision to sell and/or consume poultry meat and eggs without the need to formally negotiate with their husbands (27). The sales of poultry products play an important role in women's economy and livelihood (28). The misuse of AMs in LBM could be reduced by employing a gender-targeted approach by increasing awareness and understanding of AMU and AMR through effective communication, education, and training. Similarly, a participatory approach should be encouraged to integrate perspectives and needs of LBS to enhance behavioral changes towards AMU.

The biosecurity practices among the LBS surveyed were generally poor. Prevention is the most cost-effective way of disease management and remains the best strategy towards the sustainability of livestock health and production $(30,31)$. Implementing operable biosecurity protocols or standards within the livestock industry in Nigeria is still a constraint against the effective control of animal diseases. Past studies conducted within the poultry production systems in Ogun State and other parts of the country showed that poor biosecurity practices, hygiene, sanitary measures, and the inadequacies in management and husbandry contributed significantly to the overdependence of poultry farmers on AMs as a disease prevention strategy and to boost productivity $(9,13,16)$. The poor standards of biosecurity in LBMs have also been described in studies from Uganda (32), Mali (33), and Bangladesh (34). These authors associated poor biosecurity and hygiene measures with 1) the lack of financial means for infrastructure such as electricity, drinking water supply, waste disposal facilities, and equipment, and 2) a lack of awareness of biosecurity issues or poor compliance by LBS. It is also important to note that the poor hygiene status of LBM promotes easy transmission and fast spread of pathogens via direct and indirect contact. The LBS are at higher risk of exposure to resistant fecal pathogens due to their daily activities, which include direct contact with poultry such as slaughtering, selling poultry products, and handling animal waste (34).

In this and other reports, it was documented that on the LBMs the birds of various species, ages and breeding location were in close contact with each other as well as with wild birds $(32,33,35)$. This practice could promote concentrating, amplifying, and persistence of various pathogens within these populations and the environment. Wild migratory birds have been implicated in the introduction, maintenance, and global dissemination of different pathogens of transboundary animal diseases and zoonoses such as highly pathogenic avian influenza (HPAI), Newcastle disease, and AMR-bacteria $(35,36,37,38)$. A study conducted in Northern Egypt validated the presence of Influenza avian viruses and MDR Escherichia coli and Salmonella in captured wild birds within the LBMs, which suggests that they could act as a reservoir and disseminator of resistant bacteria (19). The study further recommended the need to understand the epidemiological role of migratory wild birds in the transmission and maintenance of AMR.

Interestingly, in this study, a negative low correlation was observed between biosecurity and AMU, though not statistically significant. Nevertheless, we demonstrated an association in the contact between LBS and the veterinarians, which result in satisfactory biosecurity practices. This confirms the role of veterinarians in influencing behavioral and attitudinal changes among livestock farmers. Detailed studies to understand perceptions, knowledge and attitude towards biosecurity, AMU and AMR among market sellers of animal products (including LBS or vendors) are crucial. Scientific data from such studies could enhance best farm practices and the adoption of a set of attitudes and behaviors among stakeholders towards promoting good biosecurity practices and reducing the risks of AMs' abuse and misuse in poultry production and marketing systems (23). Also, the use of an integrative approach for developing a research conceptual framework may be an effective tool for solving the complex challenges of biosecurity in developing countries including Nigeria. Regulatory guidelines and standards on biosecurity and food safety must be developed or improved and effectively implemented in the LBMs in Nigeria.

There is little information on the patterns and knowledge of AMU and resistance among LBS in Africa, including Nigeria. We report that wide ranges of AMs, belonging to different classes of drugs were applied by LBS. Poor AMU was observed in this study with $97.5 \%$ of the participants falling within 
this category. LBS used AMs for growth promotion, administered through the feed and water. Our report contradicts a study from Sudan, which documented $48 \%$ of poultry producers used AMs for treatment, and $8 \%$ to stimulate growth and weight gain (39). Another study documented no AMs were used for growth promotion in seven poultry farms interviewed in Thailand (40). Self-medication of birds based on previous experiences was common. This was not unanticipated as self-prescription of antimicrobials is a shared practice by livestock owners in Nigeria $(29,41,42,43,44)$. A recent study conducted among pig farmers reported that they were more convenient to self-prescribe and medicate animals due to the easy access to off-counter drugs, poor antimicrobial policies, and inadequate and expensive veterinary services (44). Several LBS reported that they have purchased AMs from human medicine pharmacies, most frequently tetracycline and chloramphenicol in capsule form for the treatment of sick birds.

The inappropriate use of AMs for livestock treatment has consequences on public health. These may include exposures to low levels of AM residues in the food chain, which may result in the increase in risk of allergic/toxic reactions, disruption of intestinal flora, chronic toxic effects and the potential emergence of resistance in the host microflora (45). In the current study, all interviewed LBS stated that they were not considering the withdrawal period, and about $33.0 \%$ stated that they slaughtered the birds within 48 hours after administering tetracycline. Our observation was similar to a study conducted in Kaduna State, Nigeria, in which it was reported that none of the poultry farmers considered the withdrawal periods of oxytetracycline, furaltadone, sulphaquinoxaline, and amprolium (46). However, it is instructed by the drug manufacturers that food animals treated with tetracycline should be withheld at least for 4-5 days before slaughtering to safeguard consumers from exposure to its residues. Unfortunately, this situation could be worse because, in many developing countries, livestock farmers and communities are uninformed of residual effects due to a lack of proper educational programs about antimicrobial usage, poor AMR and residues surveillance systems (47).

The current use and administration of furaltadone and chloramphenicol for poultry production and to birds slaughtered for human consumption also raise concerns. Nitrofurans, the most important members, which include furaltadone, nitrofurantoin, nitrofurazone, and furazolidones have been banned for use in food animal production in the EU since 1993 (48). Toxicological studies have reported that these drugs and their marker metabolites are generally genotoxic and carcinogenic, and established risk to human health from the occurrence of toxic residues in food products (49). Similarly, chloramphenicol was banned due to its mutagenicity effect and linkages with the development of aplastic anemia in humans (50). The use of banned AMs in food animal production with known public health risks needs to be reviewed by National Agency for Food and Drug Administration and Control (NAFDAC) and veterinary governing bodies of Nigeria.

Finally, the lack of significant associations between biosecurity and AMU practices and other potential risk factors in this study may be due to the low statistical power related to our small sample size ( $\mathrm{n}=40$ LBS), and outcomes from this study are interpreted with caution. The study is a collection of responses, which were self - reported and one district (Ogun central) out of three within Ogun State was investigated. A higher number of LBS randomly selected across the various districts would provide better insight and association between biosecurity practices and the pattern of AMU. Also, because a non-probabilistic sampling method was used to select participants, the outcome of these study i.e., biosecurity and AMU practices may not be representative or extrapolated to the entire LBS population in Abeokuta and Ogun State.

\section{CONCLUSION}

AMU and biosecurity practices among LBS in Abeokuta, Ogun State are generally poor. The development and implementation of standardized guidelines or policies to promote appropriate AMU and best farm biosecurity and practices by livestock stakeholders in Nigeria are critical. The measures for reducing the indiscriminate use of AMs by LBS can be most effectively implemented on the LBMs through the collaboration of all stakeholders. The LBS preferred two main sources of information, radio and seminars could be utilized by veterinary professionals and extension officers to promote AMS and internationally accepted standards. Establishing efficient surveillance systems on AMU, antimicrobial residues, and AMR in the poultry production chain can generate research data that could be used for implementing better and acceptable strategies. It is important to promote collaborations among the government, professionals, and livestock farmers to achieve responsible use of AMU in the food animal production value chains and consumer health. 


\section{CONFLICT OF INTEREST}

The authors declare that they have no potential conflict of interest with respect to the authorship and/or publication of this article.

\section{ACKNOWLEDGMENTS}

The authors acknowledge the Ogun State Ministry of Agriculture, Veterinary Services Department and all participating live bird sellers for their support. Authors are grateful to the millennium campus network (United Nations) for the Millennium fellowship awarded to Motunrayo Adetomiwa Makanjuola to conduct this preliminary study.

\section{AUTHORS' CONTRIBUTIONS}

AOO conceived and designed the work, analyzed, interpreted the data and wrote the manuscript. MM, BN and AA administered the questionnaire. AOJ performed the mapping. AO revised it critically for important intellectual content. All authors have approved the final version for publication.

\section{REFERENCES}

1. Fagbamila, I.O., Barco, L., Mancin, M., Kwaga, J., Ngulukun, S.S., Zavagnin, P., Lettini, A.A. (2017). Salmonella serovars and their distribution in Nigerian commercial chicken layer farms. PLoS One 12(3): e0173097.

https://doi.org/10.1371/journal.pone.0173097

PMid:28278292 PMCid:PMC5344354

2. Tijani, B.A., Tijani, H., Tijani, A.N. (2015). Resource use efficiency in poultry egg production in Maiduguri and Environs of Borno State, Nigeria. JEDS. 6(9): 341-356.

3. Ojo, O.E., Awosile, B., Agbaje, M., Sonibare, A.O., Oyekunle, M.A., Kasali, O.B. (2012). Quinolone resistance in bacterial isolates from chicken carcasses in Abeokuta, Nigeria: A retrospective study from 2005-2011. Niger Vet J. 33(2): 483-491.

4. Aworh, M.K., Kwaga, J., Okolocha, E., Mba, N., Thakur, S. (2019). Prevalence and risk factors for multi-drug resistant Escherichia coli among poultry workers in the Federal Capital Territory, Abuja, Nigeria. PLoS One 14(11): e0225379.

https://doi.org/10.1371/journal.pone.0225379

PMid:31751388 PMCid:PMC6872178
5. Adebowale, O.O., Ekundayo, O., Awoseyi, A.A. (2020). Female cattle slaughter and foetal wastage: A case study of the Lafenwa abattoir, Ogun state, Nigeria. Cogent Food Agric. 6(1): 1-12. https://doi.org/10.1080/23311932.2020.1809308

6. Van Boeckel, T.P., Pires, J., Silvester, R., Zhao, C., Song, J., Criscuolo, N.G., Gilbert, M., et al. (2019). Global trends in antimicrobial resistance in animals in low-and middle-income countries. Science 365(6459): eaaw1944.

https://doi.org/10.1126/science.aaw1944

PMid:31604207

7. Van Boeckel, T.P., Brower, C., Gilbert, M., Grenfell, B.T., Levin, S.A., Robinson, T.P., Teillant, A., Laxminarayan, R. (2015). Global trends in antimicrobial use in food animals. Proc Natl Acad Sci U S A. 112(18): 5649-5654.

https://doi.org/10.1073/pnas.1503141112

PMid:25792457 PMCid:PMC4426470

8. Hedman, H.D., Vasco, K.A., Zhang, L.A. (2020). A review of antimicrobial resistance in poultry farming within low-resource settings. Animals 10(8): 1264-1299.

https://doi.org/10.3390/ani10081264

PMid:32722312 PMCid:PMC7460429

9. Founou, L.L., Founou, R.C., Essack, S.Y. (2016). Antibiotic resistance in the food chain: a developing country-perspective. Front Microbiol. 7, 1881. https://doi.org/10.3389/fmicb.2016.01881 PMid:27933044 PMCid:PMC5120092

10. Food and Agriculture Organization of the United Nations (FAO) [Internet]. The FAO action plan on antimicrobial resistance 2016-2020. Supporting the food and agriculture sectors in implementing the global action plan on antimicrobial resistance to minimize the impact of antimicrobial resistance. Food and Agriculture Organization of the United Nations. [Rome].

Available from: http://www.fao.org/3/i5996e/i5996e.pdf

11. Aiki-Raji, C.O., Adebiyi, A.I., Agbajelola, V.I., Adetunji, S.A., Lameed, Q., Adesina, M., Adekanye, G., et al. (2015). Surveillance for low pathogenic avian influenza viruses in live-bird markets in Oyo and Ogun States, Nigeria. Asian Pac J Trop Dis. 5(5): 369-373. https://doi.org/10.1016/S2222-1808(14)60799-4

12. Ogundipe, F.O., Ojo, O.E., Feßler, A.T., Hanke, D., Awoyomi, O.J., Ojo, D.A., Akintokun, A.K., et al. (2020). Antimicrobial resistance and virulence of methicillin-resistant Staphylococcus aureus from human, chicken and environmental samples within live bird markets in three Nigerian cities. Antibiotics (Basel). 9(9): 588.

https://doi.org/10.3390/antibiotics9090588

PMid:32911712 PMCid:PMC7558163 
13. Fasanmi, O.G., Ahmed, S.S.U., Oladele-Bukola, M.O., El-Tahawy, A.S., Elbestawy, A.R., Fasina, F.O. (2016). An evaluation of biosecurity compliance levels and assessment of associated risk factors for highly pathogenic avian influenza H5N1 infection of live-birdmarkets, Nigeria and Egypt. Acta Trop. 164, 321-328. https://doi.org/10.1016/j.actatropica.2016.08.030 PMid:27603430

14. O’Neill, J. (2014). Antimicrobial resistance: Tackling a crisis for the health and wealth of nations. London: Review on Antimicrobial Resistance.

[Available from: https://www.naturallivestockfarming.com/wp-content/uploads/2015/09/AntibioticsUK-dec-2014-Review-paper-on-health-wealth1.pdf]

15. Behravesh, C.B. (2016). One Health: people, animals, and the environment. Emerg Infect Dis. 22(4): 766-767.

https://doi.org/10.3201/eid2204.151887

PMCid:PMC4806965

16. Yakubu,Y.,Junaidu,A.U.,Magaji,A.A., Salihu,M.D., Mahmuda, A., Shehu, S. (2011). One Health - the fate of public health in Nigeria. Asian J Med Sci. 3(1): 47-49.

17. Adebowale, O.O., Adeyemo, O.K., Awoyomi, O., Dada, R., Adebowale, O. (2016). Antibiotic use and practices in commercial poultry laying hens in Ogun state Nigeria. Rev Elev Med Vet Pays Trop. 69(1): 41-45.

https://doi.org/10.19182/remvt.31170

18. Food and Agriculture Organization of the United Nations (FAO) [Internet] (2008). Assessment of the Nigerian poultry market chain to improve biosecurity. Food and Agriculture Organization of the United Nations. [Nigeria].

[Available from: http://www.fao.org/3/ak778e/ak778e.pdf]

19. Lowenstein, C., Waters, W.F., Roess, A., Leibler, J.H., Graham, J.P. (2016). Animal husbandry practices and perceptions of zoonotic infectious disease risks among livestock keepers in a rural parish of Quito, Ecuador. Am J Trop Med Hyg. 95(6): 1450-1458. https://doi.org/10.4269/ajtmh.16-0485 PMid:27928092 PMCid:PMC5154466

20. World Medical Association. (2001). World medical association declaration of Helsinki. Ethical principles for medical research involving human subjects. Bull World Health Organ. 79(4): 373-374.

21. Seid, M.A., Hussen, M.S. (2018). Knowledge and attitude towards antimicrobial resistance among final year undergraduate paramedical students at University of Gondar, Ethiopia. BMC Infect Dis. 18(1): 312. https://doi.org/10.1186/s12879-018-3199-1 PMid:29980174 PMCid:PMC6035414
22. Agyare, C., Boamah, V.E., Zumbi, C.N., Osei, F.B. (2018). Antibiotic use in poultry production and its effects on bacterial resistance. In: Y. Kumar (Ed.), Antimicrobial resistance - A global threat (p. 22). InTech Open Science.

https://doi.org/10.5772/intechopen.79371

23. Mikecza, O., Pica-Ciamarraa, U., Felisa, A., Nizeyimanab, G., Okello, P., Brunell, C. (2020). Data on antimicrobial use in livestock: Lessons from Uganda. One Health 10, 100165.

https://doi.org/10.1016/j.onehlt.2020.100165

PMid:33117878 PMCid:PMC7582197

24. Sarker, M.S., Mannan, M.S., Ali, M.Y., Bayzid, M., Ahad, A., Bupasha, Z.B. (2019). Antibiotic resistance of Escherichia coli isolated from broilers sold at live bird markets in Chattogram, Bangladesh. J Adv Vet Anim Res. 6(3): 272-277.

https://doi.org/10.5455/javar.2019.f344

PMid:31583222 PMCid:PMC6760497

25. AlMasud, A., Rousham,E.K., Islam, M.A., Alam, M.U., Rahman, M., Mamun, A.A., Sarker, S., et al. (2020). Drivers of antibiotic use in poultry production in Bangladesh: dependencies and dynamics of a patron-client relationship. Front Vet Sci. 7, 78.

https://doi.org/10.3389/fvets.2020.00078

PMid:32185184 PMCid:PMC7058630

26. Alders, R.G.,Dumas, S.E.,Rukambile,E.,Magoke,G., Maulaga, W., Rosa Costa, J.J. (2018). Family poultry: multiple roles, systems, challenges, and options for sustainable contributions to household nutrition security through a planetary health lens. Matern Child Nutr. 14(Suppl 3): e12668.

https://doi.org/10.1111/mcn.12668

PMid:30332533 PMCid:PMC6221142

27. Dumas, S.E., Maranga, A., Mbullo, P., Collins, S., Wekesa, P., Onono, M., Young, S.L. (2018). Men are in front at eating time, but not when it comes to rearing the chicken: Unpacking the gendered benefits and costs of livestock ownership in Kenya. Food Nutr Bull. 39(1): 3-27.

https://doi.org/10.1177/0379572117737428 PMid:29226708

28. de Bruyn, J., Wong, J., Bagnol, B., Pengelly, B., Alders, R. (2015). Family poultry and food and nutrition security. CAB Reviews. 10(13): 1-9. https://doi.org/10.1079/PAVSNNR201510013

29. Awogbemi, J., Adeyeye, M., Akinkunmi, E.O. (2018). A survey of antimicrobial agents usage in poultry farms and antibiotic resistance in Escherichia coli and Staphylococci isolates from the poultry in Ile-Ife, Nigeria. J Infect Dis Epidemiol. 4(1): 47.

https://doi.org/10.23937/2474-3658/1510047 
30. Adesokan, H.K., Akanbi, I.O., Akanbi, I.M., Obaweda, R.A. (2015). Pattern of antimicrobial usage in livestock animals in southwestern Nigeria: The need for alternative plans. Onderstepoort J Vet Res. 82(1): 816.

https://doi.org/10.4102/ojvr.v82i1.816

PMid:26016985 PMCid:PMC6238793

31. Kwaghe,A.V., Vakuru, C.T., Ndahi, M.D., Abubakar,A., Iwar, V.N., Eze (2016). Proper hygiene and effective management of livestock as a Panacea for agricultural development and increase in Nigeria's gross domestic product (GDP): a review. CAB Review. 11(24): 1-21.

https://doi.org/10.1079/PAVSNNR201611024

32. Kirunda, H., Mugimba, K.K., Erima, B., Mimbe, D., Byarugaba, D.K., Wabwire-Mangen, F. (2014). Predictors for risk factors for spread of avian influenza viruses by poultry handlers in live bird markets in Uganda. Zoonoses Public Health. 62(5): 334-343. https://doi.org/10.1111/zph.12151 PMid:25154979

33. Molia, S., Boly, I.A., Duboz, R., Coulibaly, B., Guitian, J., Grosbois, V. (2016). Live bird markets characterization and trading network analysis in Mali: Implications for the surveillance and control of avian influenza and Newcastle disease. Acta Trop. 155, 77-88.

https://doi.org/10.1016/j.actatropica.2015.12.003 PMid:26708995

34. Alam, M., Rahman, M., Islam, M.A, Asaduzzaman, M., Sarker, S., Rousham, E., Unicomb, L. (2019). Human exposure to antimicrobial resistance from poultry production: assessing hygiene and waste-disposal practices in Bangladesh. Int J Hyg Environ Health. 222(18): 1068-1076.

https://doi.org/10.1016/j.ijheh.2019.07.007

PMid:31331788

35. Nabil, N.M., Erfan, A.M., Tawakol, M.M., Haggag, N.M., Naguib, M.M., Samy, A. (2020). Wild birds in live birds markets: potential reservoirs of enzootic avian influenza viruses and antimicrobial resistant Enterobacteriaceae in Northern Egypt. Pathogens 9(3): 196.

https://doi.org/10.3390/pathogens9030196

PMid:32155863 PMCid:PMC7157678

36. Hamer, S.A., Lehrer, E., Magle, S.B. (2012). Wild birds as sentinels for multiple zoonotic pathogens along an urban to rural gradient in Greater Chicago, Illinois. Zoonoses Public Health. 59(5): 355-364. https://doi.org/10.1111/j.1863-2378.2012.01462.x PMid:22353581

37. Agnew, A., Wang, J., Fanning, S., Bearhop, S., McMahon, B.J. (2016). Insights into antimicrobial resistance among long distance migratory East Canadian High Arctic light-bellied Brent geese (Branta bernicla hrota). Ir Vet J. 69, 13. https://doi.org/10.1186/s13620-016-0072-7 PMid:27651892 PMCid:PMC5024491
38. Choi, M.J., Torremorell, M., Bender, J.B., Smith, K., Boxrud, D., Ertl, J.R., Yang, M., et al. (2015). Live animal markets in Minnesota: a potential source for emergence of novel influenza a viruses and interspecies transmission. Clin Infect Dis. 61(9): 1355-1362.

https://doi.org/10.1093/cid/civ618

PMid:26223994 PMCid:PMC4599395

39. Ishak, M.A., Ali, H.M., Kheder, S.I. (2017). Prevalence and knowledge of antibiotics misuse and resistance in poultry and livestock in Khartoum State - Sudan. Sudan Med Monit. 12, 45-50.

40. Wongsuvan, G., Wuthiekanun, V., Hinjoy, S., Day, NPJ, Limmathurotsakul, D. (2018). Antibiotic use in poultry: a survey of eight farms in Thailand. Bull World Health Organ. 96(2): 94-100.

https://doi.org/10.2471/BLT.17.195834

PMid:29403112 PMCid:PMC5791776

41. Geidam, Y.A., Ibrahim, U.I., Grema, H.A., Sanda, K.A., Suleiman, A., Mohzo, D.L. (2012). Patterns of antibiotic sales by drug stores and usage in poultry farms: a questionnaire-based survey in Maiduguri, Northeastern Nigeria. J Anim Vet Adv. 11(16): 28522855.

https://doi.org/10.3923/javaa.2012.2852.2855

42. Adelowo, O.O., Okunlola, I. (2019). Field assessment of antibiotic use in fish farms in Southwestern Nigeria. Rev Elev Med Vet Pays Trop. 72(4): 187-191.

43. Oloso, N.O., Fagbo, S., Garbati, M., Olonitola, S.O., Awosanya, E.J., Aworh, M.K., Adamu, H., et al. (2018). Antimicrobial resistance in food animals and the environment in Nigeria: a review. Int J Environ Res Public Health. 15(6): 1284.

https://doi.org/10.3390/ijerph15061284

PMid:29914203 PMCid:PMC6025306

44. Adebowale, O.O., Adeyemo, F.A., Bankole, N., Olasoju, M., Adesokan, H.K., Fasanmi, O., Adeyemo, O., et al. (2020). Farmers' perceptions and drivers of antimicrobial use and abuse in commercial pig production, Ogun State, Nigeria. Int J Environ Res Public Health. 17(10): 3579.

https://doi.org/10.3390/ijerph17103579

PMid:32443741 PMCid:PMC7277550

45. Nhung, N.Y., Van, N.T.B., VanCuong, N., Duong, T.T.Q., Nhat, T.T., Hang, T.T.T., Nhi, N.T.H., et al. (2018). Antimicrobial residues and resistance against critically important antimicrobials in non-typhoidal Salmonella from meat sold at wet markets and supermarkets in Vietnam. Int J Food Microbiol. 266, 301-309.

https://doi.org/10.1016/j.ijfoodmicro.2017.12.015

PMid:29275223 PMCid:PMC5783717 
46. Kabir, J., Umoh, V.J., Audu-Okoh, E., Umoh, J.U., Kwaga, J.K.P. (2004). Veterinary drug use in poultry farms and determination of antimicrobial drug residues in commercial eggs and slaughtered chicken in Kaduna State, Nigeria. Food Contam. 15(2): 99-105.

https://doi.org/10.1016/S0956-7135(03)00020-3

47. Hosain, M.Z., Kabir, S.M.L., Kamal, M.M. (2021). Antimicrobial uses for livestock production in developing countries. Vet World. 14(1): 210-221. https://doi.org/10.14202/vetworld.2021.210-221 PMid:33642806 PMCid:PMC7896880

48. European Food Safety Authority (EFSA). (2015). Scientific opinion on nitrofurans and their metabolites in food: EFSA panel on contaminants in the food chain. EFSA J. 13(6): 4140.

https://doi.org/10.2903/j.efsa.2015.4140
49. Antunes, P., Machado, J., Peixe, L. (2006). Illegal use of nitrofurans in food animals: contribution to human salmonellosis. Clin Microbiol Infect. 12(11): 1047-1049.

https://doi.org/10.1111/j.1469-0691.2006.01539.x PMid:17002603

50. Berendsen, B., Stolker, L., De Jong, J., Nielsen, M., Tserendorj, J.E., Sodnomdarjaa, R., Elliot, T.C. (2010). Evidence of natural occurrence of the banned antibiotic chloramphenicol in herbs and grass. Anal Bioanal Chem. 397(5): 1955-1963.

https://doi.org/10.1007/s00216-010-3724-6

PMid:20431869 PMCid:PMC2886120

Please cite this article as: Adebowale O., Makanjuola M., Bankole N., Olanike A., Awoseyi A., Awoyomi O.J. Biosecurity and antimicrobial use practices in live bird markets within Abeokuta Metropolis, Southwest, Nigeria: a preliminary survey. Mac Vet Rev 2021; 44 (2): 187-202. https://doi.org/10.2478/macvetrev-2021-0024 